\title{
Assets Accounting in Local Financial Manager Perspective: Interpretive Study
}

\author{
La Ode Anto ${ }^{1}$, Unti Ludigdo ${ }^{2}$, Alimuddin ${ }^{3}$ \\ ${ }^{1}$ Doctoral Program of Economic Science, Faculty of Business and Economics, Hasanuddin University, Makassar, Indonesia \\ ${ }^{2}$ Faculty of Business and Economics in Brawijaya University, Malang East Java of Indonesia \\ ${ }^{3}$ Faculty of Business and Economics, Hasanuddin University, Makassar, Indonesia
}

\begin{abstract}
The accounting treatment of assets in local government tends to adopt an accounting system in the private sector is not as easy as imagined. The different characteristics governmental sectors as public organizations are in many ways different from private organizations lead to the views of the government in reporting its assets. This study aims to reveal the meaning of asset accounting understood by local financial management actor. In this study researchers used an interpretive paradigm with a phenomenological approach. The study shows that asset accounting is interpreted based on the source of funding, functions, and benefits of the asset. Meaning assets in the perspective of asset funding sources is understood as capital goods which only includes fixed assets. Based on the function, asset understood as economic assets and social assets. Benefits of economic assets are important, but social assets much more important in the effort to improve the welfare of society, for it is seen as an important asset to be reported.
\end{abstract}

Keywords: Asset Accounting, Local Financial Manager, Interpretive.

\section{Introduction}

Over the past decade, many countries in the world have decided to adopt accrual accounting. The accounting reform has given rise to the elaboration of public sector accounting standards. The tendency to adopt accrual accounting is usually associated with the emergence of the idea of New Public Management (NPM), which aims at modernization and rationalization of the public sector through the introduction of business management in government. Knowing and determine the financial value of an asset is considered as very essential in order to improve efficiency.

However, the value of assets on the government will not be the same as the value of assets in the company, which was established with the aim of creating economic benefits, has inputs and outputs that can be measured financially, while the government organization's goals are much broader. Basically, the government organization aimed at providing services of a social nature such as education and defense, which can not directly be measured financially. Therefore, the adoption of accounting that focuses on the financial benefits cannot give an adequate picture in the reporting of government assets.

The development of accrual accounting in the last decade has been increasingly popular in the public sector. These developments have not been separated from the debate about the suitability of terminology assets to the private sector when applied to the public sector, especially governments. The question that remains controversial is whether all government assets should be capitalized and reported in the financial statements of the government. In general, assets in the public sector were divided into two groups: financial assets and physical assets (Grubisic, et al., 2008). The group's financial assets are essentially no different characteristics when they're in the private sector as well as in the public sector. Unlike the case with a group of physical assets, especially fixed assets, have slightly different characteristics when it is in the public sector. This is related to the objectives and functions of public sector organizations that are different from the private sector. Therefore, these assets requires separate treatment so that the need for adjustments when adopting private sector accounting principles.

In connection with this, Rowles, et al. (1998) argues that the principles of business accounting can be transferred without any significant adjustments to the entire property of the government. This implies that all state-owned capital goods should be treated as an asset. Some regulatory bodies accounting standards, especially the International Public Sector Accounting Standard Board (IPSASB) recommends to recognize all capital goods owned by the government as an asset, as well as on the company. On the other hand, some people still question the suitability of duplicating the definition of assets from the private sector (companies) to the public sector (Cheng and Haris, 2000; Christiaens, 2000; Monsen, 2001). In general, they found accrual accounting, as a concept for the business sector accounting is not relevant for the activities of the government. Accrual accounting in the public sector should be designed to meet the operating environment and specific information. In fact, the results of research in recent years shows that the recognition, measurement, and disclosure of some government assets such as infrastructure assets, artistic and historic assets are still problematic (Adam, et al., 2011; Lapsley, et al., 2010).

Reform of accounting system with the introduction of accrual accounting is derived from the movement of public sector modernization. The whole processes of modernization of the public sector are often summarized in terms of NPM, which refers to a package of financial and administrative reforms in the public sector. A change in asset management and governance of public policy is regarded as the biggest challenge in the history of the implementation of the NPM. It 


\section{International Journal of Science and Research (IJSR) \\ ISSN (Online): 2319-7064}

Index Copernicus Value (2013): 6.14 | Impact Factor (2014): 5.611

is understood that reform of the public sector asset management as a major factor and one that is increasingly changing public sector organizations. There are many studies about the experience of public assets management reform in various countries (Barrett 2004).

The accounting treatment of assets in government tend to adopt an accounting system in the private sector is not as easy as imagined. Changes in the accounting system will also work well when supported with a change of mindset of human resources and operational management levels of government in this regard in the local financial management apparatus in understanding government assets.

The accounting treatment of the assets of local government can be influenced by the views of the actors of local finance managers in understanding the asset. Assets can be understood in various ways based on the nature, functions, and benefits of any assets that exist in local government. This study aims to reveal the meaning of asset accounting understood by local financial management actor. Therefore, in the next section of this paper will be preceded by a review of literature on terminology and reporting of assets of the public sector, further discussed the study design followed the research findings, and the discussion ended with the conclusion.

\section{Literature Review}

\section{Government Capital Goods; Economic Function and Social Function}

The accounting reform has given rise to the elaboration of public sector accounting standards. The tendency to adopt accrual accounting is usually associated with the emergence of the idea of NPM aimed at modernization and rationalization of the public sector through the introduction of business management in government. Knowing and determine the financial value of an asset is considered as very essential in order to improve efficiency. Basically, the government organization aimed at providing services of a social nature such as education and defense, which can not directly be measured financially. Therefore, the adoption of accounting that focuses on the financial benefits cannot give an adequate picture in the reporting of government assets (Christiaens, et al., 2012).

The concept of capital goods in the government is still being debated to this day. According to Christiaens, et al. (2012), this problem can be solved by means of a resolution on the recognition of capital goods used in the provision of government services to the public main that only requires. The definition of assets is interpreted within the limits defined status against government capital goods that reflect the objectives of the government ownership of capital goods. In the first status, the government implemented the concept of business assets to gain economic benefits. In other words the government uses capital goods which have the status of the economy, namely capital goods that generate economic benefits that flow back to the government.
Given the usefulness of the unique and important of the assets of a social nature to conservation and the nation's history, health, education, culture and environment, encouraging the government must maintain and preserve it, then it is appropriate to treat these assets as community assets owned and entrusted to government for the current and future generation (Pallot, 1990; Barton, 2000). The concept of economic benefits is used to distinguish between types of assets. The economic benefits are often interpreted to mean that the item of assets expected to generate cash inflows to the controlling entity. That is, the economic benefits are sometimes directly equated with cash flow. Because a lot of assets in the form of public goods do not generate cash inflows, it can even be said that this items is not an asset but is more akin to an obligation (Mautz, 1988). Barton, et al. (2002) argues that unlike private goods, the government as the owner does not receive the benefits of its use, because the flow of economic benefits directed to the public, and the government does not have the unlimited right to manage, as well as the assets of a trust belonging to the nation.

Due to the different roles, Mautz (1988) argues that the social assets must be distinguished, and proposes that these assets are called "facilities". Likewise Pallot (1990) concluded that social assets should be reported separately from other assets, and recommends that these assets are called "community assets". In connection with this Barton (2000) agrees with the notion of accountability separately based on several factors such as the special role of social assets (including the legacy of history as a museum collection and archives) as a public good in providing cultural services, recreation, and history to the general public either free or no cost; restrictions on the use and resale; requirements for conservation and preservation; and provision of services to the community outweigh the managing entity. Thus, the status given by the government for a capital goods will determine how the accounting treatment. Criteria for the recognition and accounting treatment of government capital goods can be described as follows: (Christiaens, et al., 2012).

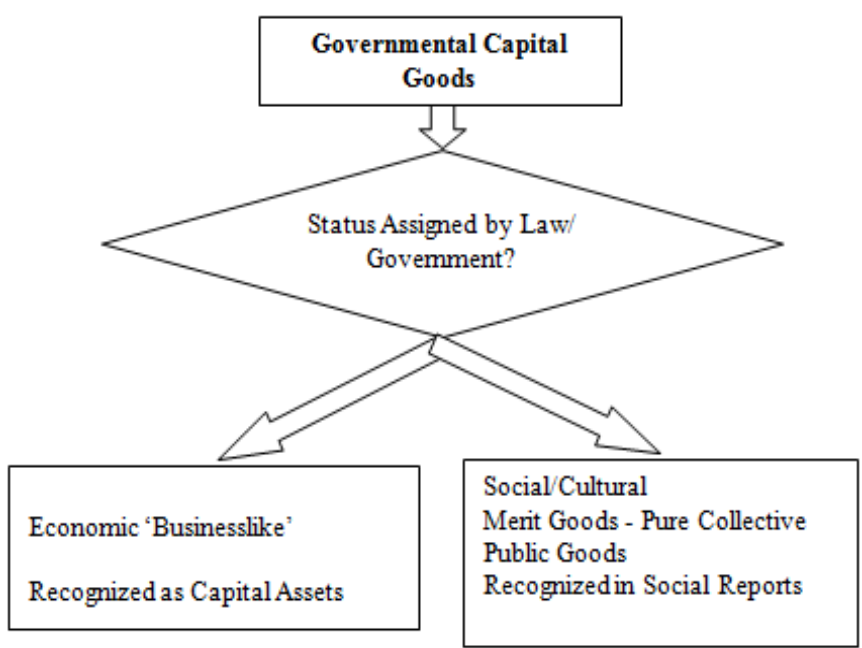

Figure1: Recognition of capital goods in public perspective 


\section{International Journal of Science and Research (IJSR) \\ ISSN (Online): 2319-7064}

Index Copernicus Value (2013): 6.14 | Impact Factor (2014): 5.611

\section{Government Capital Goods with Public Goods} Characteristics

The use of assets in the form of public goods is strictly regulated by law to ensure that the assets can be protected from improper use and must be preserved and maintained in good condition so as to have a benefit long, unlimited and can continue to provide social benefits in the future. The government's decision to put an asset into the public domain to preserve the national culture has two important implications for accounting and financial reporting. First, these assets become public assets with characteristics fundamentally different from those in the private sector; and secondly, the assets must be accounted for and reported separately from normal commercial assets of the entity as an asset belonging to the nation's confidence (Barton, 2000).

Public goods are marked with attributes that consumption of non-rival and non-excludable (Barton, 1999a). As a consequence, public goods do not meet the accounting definition of an asset is an asset that the future economic benefits that are controlled by an entity as a result of past transactions or other past events. Furthermore, because these capital goods usually cannot be sold, the economic benefits cannot be realized through sales. This definition also requires that an entity has control over an asset that can receive benefits (Barton, 2005).

The benefits of the use of public goods will flow to the general public and not to the government as the owner. Clearly, capital goods should be treated separately from the assets of government operations. Separate classification has been recommended by Mautz (1988) as a facility, Pallot (1990) as a public asset, and Barton (2000) as an asset of the trust. Public goods are provided by non-commercial and funded mainly from income taxes. Economists distinguish between private goods and public goods as a basis to justify why some of the items to be provided by government rather than by private companies (Barton, 1999b).

Definition of assets also requires owners to have control over the assets in order to obtain economic benefits from its use. Capital goods supplied for use as public goods, the benefits are directed to the general public and not to the government as the owner. Thus, although the government can control it, the benefits do not flow to the owners as well as commercial assets, but to the community as a user (Barton, 2000). Carnegie and Wolnizer (1995) suggested that, historically, the word "assets" are described as items of wealth and legal rights that can be used to pay off debt, and that the asset is defined as the wealth available to pay off the debt. Public goods are not relevant in assessing the long-term financial performance of the management of the entity because it is used for social purposes, not financial goals. Inclusion of public goods in the statement of assets and liabilities of the entity will bear representational distortions to the reader.

Public goods are precious wealth of the nation that enhances social welfare, and they should be used as efficiently and effectively as possible for social benefits. Given that the accounting information system is not exactly normal commercial and public goods do not meet the accounting requirements to be recognized as an asset or liability, alternative information system is needed to facilitate the management and accountability. An information system should be designed to suit the purpose and the environment in which the entity operates. It is necessary to ensure that the information is relevant to the purpose can be achieved (Glazer and Jaenicke, 1991; Rentschler and Potter, 1996). Full accrual accounting was developed and refined over the years to meet the needs of commercial enterprises. However, the form of accounting is not appropriate for public goods because their physical characteristics are often very different from a commercial asset. Instead, a new approach is needed that takes into account the specific characteristics of public goods (Pallot, 1990).

\section{Research Method}

This to achieve the objectives set in this study which is to explain the meaning of accounting asset that is understood by the actors of local financial management, this study uses an interpretive paradigm with a phenomenological approach. Rationale the researchers used an interpretive paradigm is this study a greater emphasis on the role of language, interpretation and understanding of the meaning of reality (asset accounting practices) as it is. In connection with this, Burrell and Morgan (1979: 28) argues that the essence of this paradigm is on the understanding forms the fundamental of the social world at the level of subjective experience of a person, and seek explanations in reality the individual consciousness and subjectivity in the framework with regard to the observation of participation to the action.

Interpretive trying to recognize the world as it approaches a subjective experience itself. The orientation is more aimed at gaining an understanding subjectively created 'as he is' (as it is) in a process that lasts (Burrell and Morgan, 1979). Use of the phenomenological approach is considered more appropriate because phenomenology is a concept has become the philosophy, research methods and perspectives surrounding of the meaning of all qualitative research derived. Other considerations used phenomenological approach is that asset accounting practices is a social phenomenon that is formed by the interaction between the various parties.

Phenomenology is a philosophical schools as well as methods of thinking introduced by Husserl who moved from the phenomenon as it appears the (Ferguson, 2001). Phenomenologies trying to think and choose what elements are derived from the ideas and elements which are derived from experience. A phenomenon which appears, is actually a reflection of a reality that cannot stand alone because it looks it is an object filled with transcendental meaning, therefore, to get the essence of truth then it must break through beyond the phenomenon looks (Basrowi and Sukidin, 2002).

As a method, phenomenology unfurled the steps to be taken to arrive at pure phenomena (the essence). Phenomenology should depart from the human subject as well as awareness and attempted to return to pure consciousness. Phenomenology teaches "back to the thing itself" free from all presuppositions (prejudice), because it is itself an object of consciousness directly in pure form (Maksum, 2008). The

\section{Volume 4 Issue 11, November 2015}




\section{International Journal of Science and Research (IJSR) \\ ISSN (Online): 2319-7064}

Index Copernicus Value (2013): 6.14 | Impact Factor (2014): 5.611

main aim of phenomenology is to study how the phenomenon experienced in consciousness, thought, and action, such as how the phenomenon valuable or aesthetically acceptable.

The use of phenomenology can reveal the essence of who is behind the meaning of the asset accounting practices and build structures that meaning. The essence of the phenomenon is the fact that no other entry into the human consciousness. So an object is exists in relation consciousness. The phenomenon is not he as seen by naked eye, but rather in the consciousness, and served with awareness as well. In other words, phenomenologies reflect direct experience of man, in so far as it refers experience (intentional) on an object (Kuswarno, 2009). To obtain the required data, researchers have conducted observation and in-depth interviews of the 18 informants who comes from the actors of local financial manager of both the executive and the legislature in Kendari Southeast Sulawesi Province of Indonesia. The data collected are then analyzed by following the flow of analysis developed by Moustakas (1994) namely: 1) Horizonalization, 2) Reduction and Elimination, 3) Textural description, 4) Structural description, and 5) Synthesis.

\section{Results and Discussion}

\section{Asset is Capital Goods: the Meaning of Assets in Sources of Funding Perspective}

The existence of assets in government organizations are in an integrated financial management system from planning, budgeting, implementation, administration/ reporting, and monitoring. The budget includes spending plan is closely related to the manner and process of procurement of assets. Therefore, an understanding of the meaning of assets and ways of reporting, among others, can be based on the type of expenditure that is used in acquiring an asset. A budget reflects the government's revenue and expenditure plans, in which, among others, have included some type of expenditure that will be used for one year. So acquisitions in the period will be based on the spending budget. In this regard, one informant said: "To be categorized as government assets when those assets are government property acquired through capital expenditure typically has the form or physical. Usually it can be used in a long period of time, more than one year "(AW, February 18th, 2015).

This indicates that the meaning of the goods (assets) acquired is based by way of the goods obtained attributed to the category of expenditure in the Local Budget. Capital expenditure becomes the basis to define and treat the goods obtained as assets in financial reporting. In this context, the acquired assets will be recorded and reported as assets in the balance sheet at the value of capital expenditures listed in the Local Budget. In practical terms, it facilitates accounting functions in performing asset recognition and recording, where the recording of the value of the asset has had a historical data base record sometimes become a major in accounting.

However, this understanding is not always smooth in the financial reporting process; because it turns the value of capital expenditure in the budget do not always reflect the real value of the existing assets in local government. It is as expressed by another informant that: "Ideally, the capital expenditure should be recognized as an asset, but it usually goes wrong budgeting, there is capital expenditure which is not an asset, real on the ground. So there is no capital expenditure into an asset but are recorded as assets so that the goods do not exist "(SR, 22 December, 2014).

Based on the narrative, it was revealed that the recording assets at the value specified on capital expenditure in the Local Budget are vulnerable to a misstatement when an error occurs in the capital expenditure budget. As a result, assets that are reported do not reflect the real value of assets. There are some assets that are listed as assets in the financial statements but the physical presence of these assets in the field does not exist.

According to informants, this occurs because of an error budgeting. Budgeting error in question is: "the existence of several components of capital expenditures for the asset should be included in the procurement of goods and services because these components are consumable goods. This is a phenomenon that applies in general to local governments, and still be one of the problems in the financial management and reporting of local government assets" (SR, December $22,2014)$. Meaning of assets owned by the government as capital goods sourced from capital spending as well understood by other actors that will be recognized and reported assets when the assets were acquired through capital expenditure. One informant said that: "The assets we report now it is a government-owned asset, whether movable or immovable obtained by removing the funds we have and through capital expenditures. So that all procurement is identified as a fixed asset will be budgeted through capital expenditure "(SD, 23 February, 2015). Based on the narrative, it can be said that the asset is understood as capital goods, government property acquired through capital expenditure with a benefit of more than one year, due to capital expenditure itself is a kind of expenditure which is carried out in the framework of the purchase/ acquisition or construction of fixed assets intangible that has the value of the benefits of more than 12 months to be used in government activities. In this context, assets are better understood as fixed assets either moving or not moving.

Goods obtained apart from capital expenditure such as goods and services expenditure are not categorized as an asset. There are several types of goods with a useful life of more than 12 months, but because the designation is not to be used in the operations of government but to be distributed (delivered) to the public, the items are not included in capital expenditures but as goods and services expenditure. It is as expressed by another informant that: "Assets because he capital expenditure. If the supply of goods and services that do not include an asset. Because the definition of an asset is based on its economic life of more than one year. So the paper is goods are used up. So consumable goods is not an asset "(MD, 8 April 2015).

Furthermore, understanding the assets as capital goods was also expressed by other informants that: "What I have seen so far that assets such as land, buildings, vehicles, computers and others. Anyway all items purchased with the capital expenditure with the system of direct payments to third

\section{Volume 4 Issue 11, November 2015}




\section{International Journal of Science and Research (IJSR) \\ ISSN (Online): 2319-7064}

Index Copernicus Value (2013): 6.14 | Impact Factor (2014): 5.611

parties. Yes, everything is for more than one year, excluding consumables such as stationery or printed material which usually runs out at the end of the period "(PM, 17 February, 2015)

Based on the description above, the asset is defined on the basis of their source of funding in the budget for capital expenditure. This basic understanding has narrowed the scope/coverage that understood the meaning of assets, where the asset is identified with capital goods owned/controlled by local governments with a useful life of more than one year. Thus the meaning of the assets in this perspective only covers physical assets in this case fixed assets, but as has been described previously that besides those assets also include other asset group. Another group of assets that are financial assets include cash, accounts receivable, a contractual right to exchange financial instruments with another entity, and the entity's equity instruments such as shares.

Understanding as mentioned above may be because in the last few years one of the major problems in the management and financial reporting of local government is the absence of asset management and reporting systems remain adequate. The local government is conducting a variety of efforts to improve the administration of fixed assets of it's sustainably. So that the fixed assets of more coloring understanding of local financial manager of the meaning of assets. In addition, the capacity of human resources in the local financial management in the management and reporting of assets remains limited also affect the level of their understanding of the asset.

As previously disclosed by Mr. Anwar earlier that "the priority now is to assets purchased or from another party to grant data collection and management of well to comply with existing regulations". This is in line with what is told by informants that: "One of the elements of financial statements that are excluded is fixed assets. The initial steps taken in making the arrangement asset, discussions with various stakeholders to identify issues related to assets" (MM, 3 December, 2014)

Assets remain a major issue in the improvement of financial management. This happens because based on the results of the audit conducted by The Audit Board of the Republic of Indonesia; the asset continues to be an element of financial statements that are not reasonable. Fixed assets are still excluded from the fairness of the presentation of the financial statements of local governments. An effort to improve the continuous administration of fixed assets has been able to contribute significantly to the quality of local government financial management.

Economic Assets and Social Assets: The Meaning of Assets in Function Perspective

Understand the meaning of assets not only in terms of the way of acquisition, but also based on the functions or the status of the asset itself. The function of assets in local government aimed at supporting the implementation of operational activities in the conduct of government services to the public. In connection with this, the informant said that "So the assets are capital goods or inventory utilized for office activities or services to the public" (LM, 6 April 2015). Based on the narrative was revealed that the assets are capital goods or inventory exploited or used in operating activities of government or public service activities. In line with this statement, further another informant said: "An asset is a wealth of local area, used to support the development, support the implementation of the tasks in the framework of public service, including for the welfare of employees and the community. The end goal is to improve the welfare of the community "(LT, 16 December, 2014).

Thus it can be said that the asset is a wealth of local area used by the government to support development activities, support the implementation of the tasks in the framework of the public service. The use of government assets aimed at improving the social welfare of society. In general, the government-owned assets used in the operations of government and public service, is expected to provide cash inflows to the government itself in the future, either directly or indirectly. Therefore, these assets intended to generate revenue in the future, these assets are referred to also as an economic asset.

Meaning asset not only as a support government operations and services to the public, but on the other hand the government is expected to provide cash inflows to the government itself in the future, either directly or indirectly. In connection with this, the informant said: "There are two kinds of assets, there used to generate income, there are also only for the public service as a highway. So is the wealth of assets that must be able to generate revenue and be used for service to the community" (SD, 28 May, 2015).

Differences in function of assets raised by these actors, in accordance with the concept put forward Christiaens, et al. (2012), that the government can implement the concept of social and business asset over its capital goods. Capital goods which have economic status are used to generate economic benefits for the government. Meanwhile, the capital goods were given status as social facilities used by the public indefinitely.

The criteria to recognize a capital goods as economic assets or social assets depending on the status or the functions provided by the government for capital goods in question, so that prospects and characteristics of capital goods themselves are not simply specify the accounting treatment. Status should be laid down by law, regulation or governmental decision. For example, when a government-owned building used as a classroom for learning, then the building was used for the purpose of social/cultural (education). However, when the building was leased to private companies (eg for the conference) is not for education, the government may decide to change the social status to a status which is more economical. Physically, the building will usually remain the same, but in terms of accounting he will be treated as economic assets.

Conversely, suppose the government is the owner of the forest where certain government agencies exploit the commercial forest. At a certain moment the government or legislators may decide to conserve forests and not exploit

\section{Volume 4 Issue 11, November 2015}




\section{International Journal of Science and Research (IJSR) \\ ISSN (Online): 2319-7064}

Index Copernicus Value (2013): 6.14 | Impact Factor (2014): 5.611

them to change their status due to social reasons. The trees in the forest are then no longer being treated as an asset, as it has become public goods without any economic benefit. Thus, the status given by the government for a capital goods will determine how the accounting treatment (Christiaens, et al., 2012). Thus the meaning of the asset can be understood as a way to determine the status/function of assets used in operations and the provision of government services to the public main. Asset interpreted within the limits defined status to the government assets that reflect the objectives of government ownership of the asset.

Functions of government assets as economic assets and social assets also expressed by informants who said that "All the assets in a local area should be used primarily for the benefit of the general public. Besides, it also can bring in investment or money" (SM, 28 May, 2015). The narrative indicates that the asset utilization pursued in order to generate income (cash flow in the future).

Determination of the status of the asset by the government will determine the accounting treatment of capital goods of local government. Capital goods with the status of economic assets must be reported as assets in the statement of financial position, while the capital goods with a social asset status does not meet the criteria to be reported as assets in the statement of financial position. Social values of the assets of social functioning difficult to take measurements and economic assessment will ignore the benefits and social value of the asset. Social assets do not meet the criteria of the definition of an asset because the asset did not provide cash flow in the future to local governments, but rather provide social benefits that flow to the community.

Economic value important but far more important social value: the meaning assets in benefits perspective

As mentioned previously, that from the standpoint of its function, the actors of local financial managers interpret valuable economic asset and socially valuable asset. As an economic asset, the asset is based on the results of field observations generally have characteristics that can provide economic value to the government in the form of receiving income in the future. In contrast to the social assets, these assets often do not provide economic benefits for the government as a source of income but as a social asset can provide social value to the community in the form of facilities and enjoyment that is needed by society. Based on the results of observation, social assets is considered important by the public because it has a special characteristic that is as social facilities, can be used by all people without discrimination and the government fund the provision of these assets are wholly or largely from tax revenues.

Based on usage, social assets consist of two kinds. First, the goods merit (merit goods) that social assets owned and used by the government in providing social services to the community on an individual basis such as schools, hospitals, and others. Second, public goods (pure collective public goods) that social assets can be used by all people without discrimination such as parks and historical heritage assets. Public goods can be used by all segments of society together and difficult to levy payments. This item has properties of non-rival and non-exclusive, in which the consumption of goods by an individual does not reduce the amount of goods available for consumption by other individuals and everyone is entitled to enjoy the benefits of the goods.

In connection with this, (Barton, 2000) suggests some important characteristics of social assets for accounting purposes as follows: (1) Managed by the government for social purposes instead for government administrative purposes or financial gain; (2) Operation is largely funded by the government of tax revenue and/or from private donations; levies, if any, is usually only a small portion of the necessary funds; (3) Must be maintained and kept in good condition for the enjoyment of present and future; (4) Not for sale; (5) Open to the public and the benefits flowing to the public not to the entity manager (government); (6) The public is encouraged to use them for free or very low cost of entry.

The government's decision to put an asset into the public domain (social) in order to promote and preserve the culture of the nation, has two important implications for accounting and financial reporting. First, these assets become social assets and the assets must be accounted for and reported separately from the assets of the normal operations of government as social assets belonging to the local government. The local government made the decision to provide social assets is determined on the basis of the consideration that social values are embodied in social assets exceeds the economic value of the financial costs of providing these assets. That is social value exceeds the economic value. In this way the government believes will be able to improve the social welfare of society.

This is consistent with the narrative informant that "all assets in a local area should be used primarily for the benefit of the general public. Besides, it also can bring in investment or money" (SM, 28 May, 2015). Furthermore, another informant also said that "an asset is a wealth that should be able to generate revenue and be used for service to the community. More to the public services, profit is not the main goal" (SD, 28 May, 2015). That is, the asset utilization of local governments is preferred for the sake of social services to the community.

Given the very important social asset functions in social services to the community, then these assets need to be recorded and managed well by the government. Related to this, the informant said: "So the asset data collection is very important to know how the assets are movable and immovable. In addition to movable and immovable assets was, in fact there seems to government assets have not been recorded as archaeological relics and historical heritage. Data collection is an important asset as a form of travel of Kendari from the first or the government of Kendari from time to time and as a form of appreciation for our predecessors" (SN, 25 February, 2015).

Based on the narrative, data collection and reporting of government assets becomes a very important thing to do. Historical heritage assets as a social asset are considered very important to be recorded and reported by the government, because it is recognized that the historical heritage assets have not been recorded properly. Data collection and

\section{Volume 4 Issue 11, November 2015}




\section{International Journal of Science and Research (IJSR) \\ ISSN (Online): 2319-7064}

Index Copernicus Value (2013): 6.14 | Impact Factor (2014): 5.611

reporting of important historical legacy assets to be done as a form of appreciation of the historical heritage of the nation comes from its predecessors.

Benefits provision historical heritage assets as public goods (pure collective public goods) has a characteristic that is characterized by attributes that consumption of non-rival and non-exclusive. So, when people visit museums, art galleries and so on, they do not reduce the volume of the services available to other potential users and the service is non-rival because they are shared with all users. Furthermore, the consumption of public goods is non-exclusive because all citizens have the same access rights to enjoy the benefits of the asset and no citizen can be denied access from other community members (Barton, 1999a).

Therefore, the historical heritage assets as public goods are provided together for users, individual users do not acquire ownership rights to private. They may only be used in the manner specified in the regulations that have been set by the government. Furthermore, its use does not harm/ damage it in any way and do not shorten its age. As an asset that serves the social, historical heritage assets should not be included in the government's balance sheet as an asset, and not become part of the statement of financial position of the government. Nevertheless, the historical heritage assets such social functioning should be reported in the financial statements (for example in the form of notes to financial statements) accompanying balance sheet so that the public can obtain comprehensive information on all government assets as well as capital goods which have social status. Financial statements must be able to present descriptive information about the nature and purpose of the operation of these assets, a list of assets under management, maintenance activities are carried out, the number of visitors and the level of satisfaction, and so forth (Christiaens, et al., 2012).

\section{Conclusion}

The different characteristics governmental organizations as a public institution with private organizations lead to the government's perspective on the meaning of its assets. Purport to assets are more influenced by the views of the actors of local financial managers in understanding the asset. Asset interpreted based on the source of funding, functions, and benefits of any assets that exist in local government. Based on the results of meanings carried over, then the meaning of assets that are understood by the actors of local financial manager is the meaning and significance of funding sources asset functions. Meaning of sources of funding in the acquisition of the asset, the asset is understood as capital goods which are used to support the operations of government. An item is considered as an asset when funded from capital expenditure. Capital expenditure becomes the basis to define and treat the goods obtained as assets in financial reporting. In this context, the acquired assets will be recorded and reported as assets in the balance sheet at the value of capital expenditures listed in the Local Budget.

Asset understood as capital goods acquired through capital expenditure with a benefit of more than one year, due to capital expenditure itself is a kind of expenditure which is carried out in the framework of the purchase/acquisition or construction of fixed assets tangible that has value benefit of more than 12 (twelve) months to be used in government activities. In this context, assets are better understood as fixed assets either moving or not moving. Goods obtained apart from capital expenditure such as spending on goods and services are not categorized as an asset. This basic understanding has narrowed the scope/coverage that understood the meaning of assets, where the asset is identified with capital goods owned/controlled by local governments with a useful life of more than one year. Thus the meaning of the assets in this perspective only covers physical assets in this case fixed assets, but those assets besides there are also other groups of assets. Another group of assets that are financial assets include cash, accounts receivable, a contractual right to exchange financial instruments with another entity, and the entity's equity instruments such as shares.

Understanding as mentioned above may be because in the last few years one of the major problems in the management and financial reporting of local government is the absence of asset management and reporting systems remain adequate. The local government is conducting a variety of efforts to improve the administration of fixed assets of it's sustainably. So that the fixed assets of more coloring understanding of local financial manager of the meaning of assets. In addition, the capacity of human resources in the local financial management in the management and reporting of assets remains limited also affect the level of their understanding of the asset. Furthermore, the meaning of an asset based on its function understood as economic assets and social assets. Economic assets is defined as a government-owned assets used in the operations of government and the public service is expected to provide cash inflows to the government itself in the future, either directly or indirectly. These assets are intended to generate revenue for the government in the future.

Social assets is defined as a government-owned assets used in the operations of government and the public service are not expected to bring cash inflows to the government, but its benefits flow directly to the people who use it. These assets serve as dedicated to the enjoyment of social and social welfare of society. Asset utilization pursued in order to generate revenue. Social assets is very important that the government make a special treatment to express it as an asset that serves as a social facility, open without discrimination to all members of the community, with little or no cost. These assets provided for a social purpose is not to generate revenue, and the government fund the provision of these assets are wholly or largely from tax revenues.

The use of social assets regulated by government regulations to ensure that these assets can be protected from improper use and must be preserved and maintained in good condition so that it has a longer useful life, unlimited and can continue to provide social benefits in the future. The government made the decision to provide social assets is determined on the basis of the consideration that they consider important enough benefits to do so, which the government considers that social values are embodied in social assets exceeds the 


\section{International Journal of Science and Research (IJSR) \\ ISSN (Online): 2319-7064}

Index Copernicus Value (2013): 6.14 | Impact Factor (2014): 5.611

economic value of the financial costs of providing these assets. That is, the asset utilization of local governments is preferred for the sake of social services to the community. In this way, the government is confident will be able to improve the social welfare of society.

Based on usage, social assets consist of two kinds. First, the merit goods that social assets owned and used by the government in providing social services to the community on an individual basis such as schools, hospitals, and others. Second, pure collective public goods that social assets can be used by all people without discrimination such as parks and historical heritage assets. Public goods can be used by all segments of society together and difficult to levy payments. The public good has the nature of a non-rival and nonexclusive, in which the consumption of goods by an individual does not reduce the amount of goods available for consumption by other individuals and everyone is entitled to enjoy the benefits of the goods.

Historical heritage assets as a social asset are considered very important to be recorded and reported by the government, because it is recognized that the historical heritage assets have not been recorded properly. Data collection and reporting of important historical legacy assets to be done as a form of appreciation of the historical heritage of the nation comes from its predecessors. Not historical heritage assets such as economic goods, where the government as the owner does not receive the benefits of its use, because the flow of social benefits to the community focused. As an asset that serves the social, historical heritage assets should not be included in the government's balance sheet as an asset, and not become part of the statement of financial position of the government. Nevertheless, the historical heritage assets such social functioning should be reported in the financial statements (for example in the form of notes to financial statements) accompanying balance sheet so that the public can obtain comprehensive information on all government assets as well as capital goods which have social status.

\section{References}

[1] Adam, B., Mussari, R. and Jones, R. 2011. The Diversity of Accrual Policies in Local Government Financial Reporting: An Examination of Infrastructure, Art and Heritage Assets in Germany, Italy and the UK. Financial Accountability \& Management, 27(2), pp. 106-133.

[2] Barret, P. 2004. Financial Management in The Public Sector-How Accrual Accounting and Budgeting Enhances Governance and Accountability. The Proceeding of Challenge of Change: Driving Governance and Accountability, Singapore.

[3] Barton, A.D. 1999a. A Trusteeship Theory of Accounting for Natural Capital Assets. Abacus, 35(2), pp. 207-223.

[4] Barton, A.D. 1999b. Public and Privat Sector Accounting \pm the Non Identical Twins. Australian Accounting Review, 9(2), pp. 22-31.

[5] Barton, A.D. 2000. Accounting for Public Heritage Facilities - Assets or Liabilities of The government?
Accounting, Auditing \& Accountability Journal, 13(2), pp. 219-236.

[6] Barton, A.D., Carnegie, G.D., Wolnizer, P.W. and Newberry, S. 2002. Public Sector Accounting: A Common Reporting Framework? A Rejoinder. Australian Accounting Review, 12(3), pp. 41-50.

[7] Barton, A.D. 2005. The Conceptual Arguments Concerning Accounting for Public Heritage Assets: A Note. Accounting, Auditing \& Accountability Journal, 18(3), pp. 434-440.

[8] Basrowi and Sukidin. 2002. Qualitative Research Methods: Micro Perspective. First Edition. Surabaya: Insan Cendekia.

[9] Carnegie, G.D. and Wolnizer, P.W. 1995. The Financial Value of Cultural, Heritage and Scientific Collections: An Accounting Fiction. Australian Accounting Review, 5(1), pp. 31-47.

[10] Carnegie, G.D. and Wolnizer, P.W. 1999. Unravelling the Rhetoric about the Financial Reporting of Public Collections as Assets. Australian Accounting Review, 9(1), pp. 16-21.

[11]Cheng, R.H. and Harris, J.E. 2000. External Reporting of Capital Assets: A Sources and Uses Model. In Caperchione, E. and Mussari, R. (Eds), Comparative Issues in Local Government Accounting, Kluwer Academic Publishers, London, pp. 191-209.

[12] Christiaens, J. 2000. Municipal Accounting Reform in Flanders: An Empirical Study of the Outcomes. In Caperchione, E. and Mussari, R. (Eds), Comparative Issues in Local Government Accounting, Kluwer Academic Publishers, Dordrecht, pp. 103-124.

[13] Christiaens, J., Rommel, J., Barton, A., and Everaert, P. 2012. Should All Capital Goods of Governments be recognised as Assets in Financial Accounting? Baltic Journal of Management, 7(4), pp. 429-443.

[14]Ferguson, H. 2001. Phenomenology and Social Theory. In George Ritzer and Bary Smart. (Eds). Handbook of Social Theory. London, California, New Delhi: Sage Publications Ltd.

[15] Glazer, A.S. and Jaenicke, M.R. 1991. The Conceptual Framework, Museum Collections and User orientated Financial Statements. Accounting Horizons, December, pp. 28-43.

[16] Grubisic, M., Nusinovic, M. and Roje, G. 2008. From Accountable Government to Public Asset Management Reform and Welfare. Privredna Kretanja I Economska Politika, 117, pp. 59-117.

[17] Kuswarno, E. 2009. Communication Research Methods: Phenomenology, Conception, guidelines, and Examples of research. Bandung: Widya Padjajaran.

[18] Lapsley, I., Miller, P. and Panozzo, F. 2010. Accounting for The City. Accounting, Auditing \& Accountability Journal, 23(3), pp. 304-324.

[19]Likierman, A. 1994. Management Accounting in UK Central Government: Some Research Issues. Financial Accountability and Management, 10(2), pp. 93-116.

[20] Maksum, A. 2008. Introduction to Philosophy: From the Classical Period Up to Postmodernism. First Edition. Yogyakarta: Ar-Ruzz Media. 
[21] Mautz, 1988. Monuments, Mistakes and Opportunities. Accounting Horizons, 2(2), pp. 123-128.

[22] Monsen, N. 2001. Cameral Accounting and Cash Flow Reporting: Some Implications for Use of the Direct or Indirect Method. European Accounting Review, 10(4), pp. 705-724.

[23] Moustakas, C.E. 1994. Phenomenological Research Methods. United States of America: Sage Publications.

[24] Rentschler, R. and Potter, B. 1996. Accountability versus Artistic Development: The Case for Nonprofit Museums and Performing Arts Organizations. Accounting, Auditing \& Accountability Journal, 9(5), pp. 100-113.

[25] Rowles, T., Hutton, B. and Bellamy, S. 1998. Accounting for Infrastructure Assets: The Case of Land under Roads. Paper Presented at Annual Conference of Accounting Association of Australia and New Zealand: Adelaide. 